\title{
GONAD DEVELOPMENT AND REPRODUCTION IN THE MONOECIOUS SPECIES CHLOROPHTHALMUS AGASSIZI (ACTINOPTERYGII: AULOPIFORMES: CHLOROPHTHALMIDAE) FROM THE SARDINIAN WATERS (CENTRAL-WESTERN MEDITERRANEAN)
}

\author{
Serenella CABIDDU*, Maria Cristina FOLLESA, Cristina PORCU, and Angelo CAU \\ Department of Animal Biology and Ecology, University of Cagliari, 09126 Cagliari, Italy
}

\begin{abstract}
Cabiddu S., Follesa M.C., Porcu C., Cau A. 2010. Gonad development and reproduction in the monoecious species Chlorophthalmus agassizi (Actinopterygii: Aulopiformes: Chlorophthalmidae) from the Sardinian waters (central-western Mediterranean). Acta Ichthyol. Piscat. 42 (2): 161-177.
\end{abstract}

\begin{abstract}
Background. The shortnose greeneye, Chlorophthalmus agassizi Bonaparte, 1840, is a species with a circumglobal distribution and is among the most abundant commercial fishes in some Mediterranean areas. The knowledge of the biology and ecology of this species is poor and geographically limited, then the aim of this study is to provide a contribution to the knowledge on the reproductive biology of this monoecious deep-sea fish in Sardinian waters.
\end{abstract}

Materials and Methods. In this paper the morphology and the development of the gonads, the mean size at maturity, the monthly evolution in the percent frequency of the maturity stages, and of the indices related to reproduction of the shortnose greeneye were examined. Individuals were caught by trawls, between 270 and $504 \mathrm{~m}$ of depth in the Sardinian seas.

Results. The ovarian pattern is of an asynchronous type, characterized by releasing of eggs in successive batches. Seven stages of development for the ovary and four for the testis were identified on the basis of macroscopic and histological features. The female portion is the most evident component and shows a later maturation than the male portion. The spawning period is unique and takes place from May to September.

Conclusion. The identification of spawning period and the adopted reproductive strategy is essential to obtain a better understanding of its biology and a good management of its fisheries.

Keywords: Chlorophthalmus agassizi, hermaphroditism, reproduction, histology, deep-sea fish

\section{INTRODUCTION}

The shortnose greeneye, Chlorophthalmus agassizi Bonaparte, 1840, is a circumglobal species found in temperate and tropical regions. This species is distributed in the Western Atlantic from Canada to northern South America, in the Eastern Atlantic from Spain to Senegal, and in the Mediterranean Sea (Bini 1970, Robins and Ray 1986, Scott and Scott 1988). Young stages are pelagic, living near the surface, while the adults are demersal, near the mud and clay bottoms, at the 50 to $1000 \mathrm{~m}$ depth range, mainly between 350 and $450 \mathrm{~m}$ (Fischer et al. 1987). C. agassizi lives between $150 \mathrm{~m}$ and $700 \mathrm{~m}$ in the Italian seas (Relini et al. 1999). Recently, it has been caught between $70 \mathrm{~m}$ to $1163 \mathrm{~m}$ in the South Sardinian waters (Follesa et al. 2010).

The knowledge of the biology of C. agassizi is poor out of the Mediterranean Sea. Mead (1959) observed an adult specimen captured in the Gulf of Mexico indicating that this species is monoecious and the gonad appears in the form of a combined gonad (ovotestis), with neither component mature. In the Mediterranean, although in some areas, such as the Sardinian and Sicilian seas, it is among the most abundant commercial fish (Cau and Mura 1978, Relini et al. 1999, Follesa et al. 2004b) few studies have been carried out. These studies are mainly related to distribution, population structure, life strategies (Anastasopoulou et al. 2006, D’Onghia et al. 2006) and diet in the Ionian Sea, the Aegean Sea, and Sardinian waters (Kabasakal 1999, Cabiddu et al. 2005, Anastasopoulou and Kapiris 2007). In Sardinian seas, some aspects of the reproductive biology of C. agassizi, based only on histological criteria, such as the identification of oocyte and male sex cells were studied by Follesa et al. (2004a).

\footnotetext{
* Correspondence: Dr. Serenella Cabiddu, Dipartimento di Biologia Animale ed Ecologia, Università di Cagliari, Viale Poetto 1, 09126 Cagliari, Italy, phone: (+39 070) 675 8044, fax: (+39 070)675 8022, e-mail: cabiddus@unica.it
} 
In recent years the catches of this species by the commercial fishery in Sardinian waters have decreased, while a constant local demand was registered. In view of the importance of C. agassizi to the commercial fishery in these areas, a comprehensive study of the reproductive biology of the species is necessary for the management of this resource. Thus, the objective of this paper is to provide a contribution to the knowledge about the reproduction of $C$. agassizi through the study of individuals in the Sardinian seas (central-western Mediterranean). We analyzed the morphology and development of the gonads using both macroscopic observations and histological techniques in order to define the gonads' developmental stages and identify the spawning period through the analysis of the percentage of occurrence of the different stages of development of both components of the ovotestis. Moreover, the length at first sexual maturity, and the evolution in the percent frequency of the indices related to reproduction and the metabolism of this species were analyzed.

\section{MATERIALS AND METHODS}

Samples of Chlorophthalmus agassizi were collected monthly, between January 2002 and October 2005, from commercial trawls carried out at a depth between $270 \mathrm{~m}$ and $504 \mathrm{~m}$ in the Sardinian Channel (Southern Sardinia), using a bottom otter trawl with a $20 \mathrm{~mm}$ cod end stretched mesh. The specimens were sampled directly on board in proportion to size structure.

For each specimen the total length (TL, in mm), standard length (SL, in $\mathrm{mm}$ ), total weight (TW, in $\mathrm{g}$ ), and eviscerated weight (EW, in $\mathrm{g}$ ) were determined. The gonad ( $\mathrm{GW}$, in $\mathrm{g}$ ) and liver ( $\mathrm{LW}$, in $\mathrm{g}$ ), were removed, weighed, and blotted dry.

Determination of the maturity stages of the female portion of the gonads was processed using both macroscopic observations, according to dimension and colour (Pantone Matching System, Carlstadt, NJ, USA), and histological techniques, while it was done, for the male portion of the gonad, only by means of histology. The gonads of 1413 specimens were described and photographed; a sub-sample of 211 gonads, selected by size from each monthly sample, was treated by histology; then a mid-section, of each gonad, was fixed in Carnoy's solution (72 h); afterwards it was dehydrated in an ascending series of alcohols (95\% 12/24 h, 100\% $24 \mathrm{~h}$ ), embedded in resin (in a vacuum for $24 \mathrm{~h}$ ), sectioned using a LKB Historange Microtome at a thickness of $3 \mu \mathrm{m}$, oven-dried $\left(45^{\circ} \mathrm{C}\right.$ for $\left.48 \mathrm{~h}\right)$, and finally stained with sodium iodoeosine and Toluidine Blue following Dominici’s method (Mazzi 1977).

Stages of oocytes and sperm cells development were identified, at 40-200 $\times$ magnification using an optic microscope (Labrolux 12); they were classified according to the gonad scale maturation of Forberg (1982) re-adapted by Follesa et al. (2004a) to the studied species; whereas, the identification of the stages of development of the testicular germinal cells was based on the spermatogenic differentiation developed by Grier (1981).
For each stage, only oocytes which have been sectioned through the nucleus were counted; their minimum and maximum diameters have been measured using a graduated ocular. The nucleoplasmic ratio (NPR) was calculated using the average diameter:

$$
\mathrm{NPR}=V n\left(V_{c}-V n\right)^{-1}
$$

where $V n=$ nucleus volume and $V c=$ cytoplasm volume $=$ cell volume - nucleus volume.

Stages of gonad maturity were classified on the basis of the presence of oocytes in the more advanced stages of development for the female portion of the gonad, and on the relative abundance of the different spermatogenic cells for the male portion.

The mean size at maturity $\left(\mathrm{TL}_{50}=\right.$ length at which $50 \%$ of the specimens in the population were mature), was determined, only on specimens collected during the reproductive season, separately for the female and the male portion using a logistic function:

$$
P=\left[1+e^{-b(\mathrm{TL}-\mathrm{TL} 50)}\right]^{-1}
$$

where $P$ is the proportion of mature fish at length TL; $b$ is the slope of the maturity curve, and $\mathrm{TL}_{50}$ is the length at first maturity $=a / b$ where " $a$ " is the intercept and " $b$ " the slope.

Sexually mature individuals were defined as those with testes in the mature and spent stages and ovaries in early developing or more advanced stages.

The spawning period was identified by analysing both the monthly evolution in the percent frequency of the maturity stages and of the indices related to reproduction and its metabolism as:

the gonadosomatic index GSI $=100 \mathrm{GW} \cdot \mathrm{EW}^{-1}$,

the hepatosomatic index HSI $=100 \mathrm{LW} \cdot \mathrm{EW}^{-1}$, the condition factor $K=100 \mathrm{EW} \cdot \mathrm{SL}^{-3}$.

To insure that only adult fish (potentially mature) were used to determine these indices, the size at maturity estimate was made by determining the minimum size of specimen that was sexually mature.

Comparisons among GSI, HSI, $K$, and mean diameter of oocytes for each maturation stage, were performed using the Kruskal-Wallis test. When differences were significant, the nonparametric multiple comparisons test (Q) proposed by Dunn (1964) was performed (Hollander and Wolfe 1973, Zar 1996).

\section{RESULTS}

In this study we analyzed 1413 specimens, with a size range between 4.7 and $20.4 \mathrm{~cm}$ TL and a mean total length \pm SD of about $13.0 \pm 2.3 \mathrm{~cm}$.

Macroscopic and histological analysis (Figs. 1-19) revealed that the gonads were made up of two distinct components, an ovarian and a testicular one, separated by connective tissue. The ovotestis presented a double sacciform structure, stretched along the dorsal mid-line of the abdominal cavity, below the lower third of the stomach. The ovary is always the most evident component of the ovotestis. The testicular component lies dorso-medially to the ovarian one, and is made up of seminiferous tubules with spherical cysts, inside of which the spermatogenic 
lineage cells develop. Each testicular component ends with a deferent duct that leads outside, close to the urinary duct and behind the oviduct. The oviduct is unique and gathers the mature sexual products of both ovaries; it expands between the last intestinal tract and the urinary duct, and leads outside to a large cavity surrounded by a pigmented membrane.

Ovarian cycle. The shape, dimension, and colour of the ovaries change depending on the developmental stage. The ovaries initially appear white-translucent in colour, and become increasingly white-yellow, as the oocytes accumulate yolk, until the spawning. The diameter of the oocytes increases, in proportion with development, while the nucleoplasmic ratio decreases due to the growing storage of yolk reserves and to the progressive migration of the nucleus toward the animal pole until its disappearance.

Macroscopic and histological analysis allowed us to identify seven stages of development, based on: morphology, external colour, most advanced oogenic stages, relative abundance of the various stages of oocyte development, and presence of postovulatory follicles (POF) (Figs. 1-14): 1. Virgin. Ovaries of young immature specimens $(n=185$; range 4.7-14.9 cm TL; mean $\pm \mathrm{SD}=10.2 \pm 1.8$ ), that still have not spawned, are thin and translucent in colour with a tubular appearance and are adherent to the dorsal midline of the abdominal cavity; they occupy approximately a third of the length of the cavity. Eggs are not yet visible to the naked eye. This stage is characterized by the primary growth phase, with oogonia $(\mathrm{O})$ nests and primary oocytes (PO) having a strongly basophilic and rather homogeneous cytoplasm and a nucleus containing one voluminous or some small nucleoli $(n=2476$; range $15-147 \mu \mathrm{m}$; mean $\pm \mathrm{SD}=50.3 \pm 15.9 \mu \mathrm{m} ; \mathrm{NPR}=0.211)$ (Figs. 1,8).

2a. Developing/Virgin. Ovaries of these specimens $(n=641$; range $8.1-19.6 \mathrm{~cm} \mathrm{TL}$; mean $\pm \mathrm{SD}=13.2 \pm 1.8 \mathrm{~cm}$ ) are of a very small size and white-translucent in colour. The ovaries occupy one-half of the length of the cavity. The eggs are still not visible to the naked eye. Oocytes at the lipid globule stage (LGS) are present with weakly basophilic cytoplasm, which contain lipid globules. The diameter of these oocytes $(n=745)$ ranges between 63 and $234 \mu \mathrm{m}$, with a mean diameter of about $111.8 \mu \mathrm{m}(\mathrm{SD}=36.9)$ $(\mathrm{NPR}=0.198)$ (Figs. 2, 9).

2b. Early developing. Ovaries of developing specimens $(n=141$; range 9.7-20.4 cm TL; mean $\pm \mathrm{SD}=13.4 \pm 2.0$ $\mathrm{cm}$ ) are white/pale yellow (PMS 607) in colour and are larger in volume and length (two-thirds of the length of the cavity) than those of previous stages. The eggs become visible to the naked eye. Oocytes at the Primary yolk granule stage (Y1) present lipid globules and in addition protein yolk granules scattered in the cytoplasm) (Y1 oocyte, $n=82$; range $183-417 \mu \mathrm{m}$; mean $\pm \mathrm{SD}=$ $244.2 \pm 34.5 \mu \mathrm{m} ; \mathrm{NPR}=0.056$ ) (Figs. 3,10$)$.

2c. Late developing. The ovaries are pale yellow (PMS 1205) in colour and occupy three-quarters of the length of the abdominal cavity of the specimens $(n=79$; range $10.6-17.4 \mathrm{~cm}$ TL; mean $13.4 \pm 1.7 \mathrm{~cm})$. The eggs are vis- ible to the naked eye. Oocytes at the secondary yolk granule stage (Y2) are found with an acidophilous cytoplasm and an increase in number and size of yolk granules which started to coalesce into progressively larger drops (Y2 oocyte, $n=153$ range $216-489 \mu \mathrm{m}$; mean $\pm \mathrm{SD}=357.9 \pm 52.7$; $\mathrm{NPR}=0.021)$; tertiary yolk granule stage (Y3) oocytes are also visible (Y3 oocyte, $n=4$; range $471-510 \mu \mathrm{m}$; mean $\pm \mathrm{SD}=492.8 \pm 17.7 \mu \mathrm{m})$. In this $\mathrm{Y} 3$ oocytes the yolk granules were completely joined together like the lipid vesicles. The nucleus migrated to the periphery of the oocyte until it disappeared completely (Figs. 4, 11).

3. Ripe/running. The ovaries, typical of mature specimens ( $n=241$; range 10.9-18.9 cm TL; mean $\pm \mathrm{SD}=14.2 \pm 1.5 \mathrm{~cm})$, are pale yellow in colour (PMS 1215), turgid and occupy the entire ventral cavity. The eggs reach considerable sizes that make them visible to the naked eye. Microscopically, oocytes are at the hydrated stage $(\mathrm{H})$ and are ready for spawning (H oocyte, $n=5$; range $300-472 \mu \mathrm{m}$; mean $\pm \mathrm{SD}$ $=356.6 \pm 66.5 \mu \mathrm{m})$. Finally, we have also found some post-ovulatory follicles (POF), consisting of residual follicle layers degenerating after ovulation, and giving evidence of past spawning (Figs. 5, 12).

4a. Post-spawning. The ovaries of post spawning specimens $(n=74$; range 10.9-19.4 $\mathrm{cm} \mathrm{TL}$; mean $\pm \mathrm{SD}=14.7 \pm 2.3 \mathrm{~cm})$ lose, after the deposition of the eggs, the characteristic turgidity of the preceding stages. The ovaries are pale yellow in colour (PMS 1215), such as the previous stage and occupy two-thirds of the length of the cavity. The eggs that are not extruded undergoing resorption and assume a dark orange (PMS 153) colour that confers to the gonad an irregular appearance. Post-ovulatory follicles (POF) can be seen (Figs. 6, 13).

4b. Spent. The ovaries $(n=52$; range $11.2-19.5 \mathrm{~cm}$ TL; mean $\pm \mathrm{SD}=14.9 \pm 2.0)$ become red in colour due to intense blood irrigation. Oocytes at the atretic stage (AT) and many post-ovulatory follicles (POF) are present (Figs. 7, 14).

In the ovaries of this species, a gradual increase in the percentage of oocytes at the lipid globule stage from immature to mature stages and an increase of vitellogenic oocytes during the ovarian development were observed (Fig. 20). The morphometry of the ovarian cells revealed that primary oocytes and lipid globule stage oocytes exhibit a variation in diameter during maturation, with significant differences among the stages (KW test, $P<0.05$ ). Primary oocytes increased in size from the virgin (1) to developing stages $(2 \mathrm{a}, 2 \mathrm{~b}$, and $2 \mathrm{c})$, then decreased from developing to running stages (3), (Q test $P<0.05$ ). Lipid globule stage oocytes increased in size from developing (2a) to running (2b) stages ( $Q$ test $P<0.05$ ), values remaining high with no significant variation in the following stages $(\mathrm{Q}$ test $P>0.05)$. The yolk granules oocytes showed a modest variation in diameter during vitellogenesis with no significant differences among the gonad stages (KW test, $P>0.05$ ).

Testicular cycle. For the testicular component of the gonad, a four-stage scale of maturation was established based on spermatogenesis and on the relative abundance 


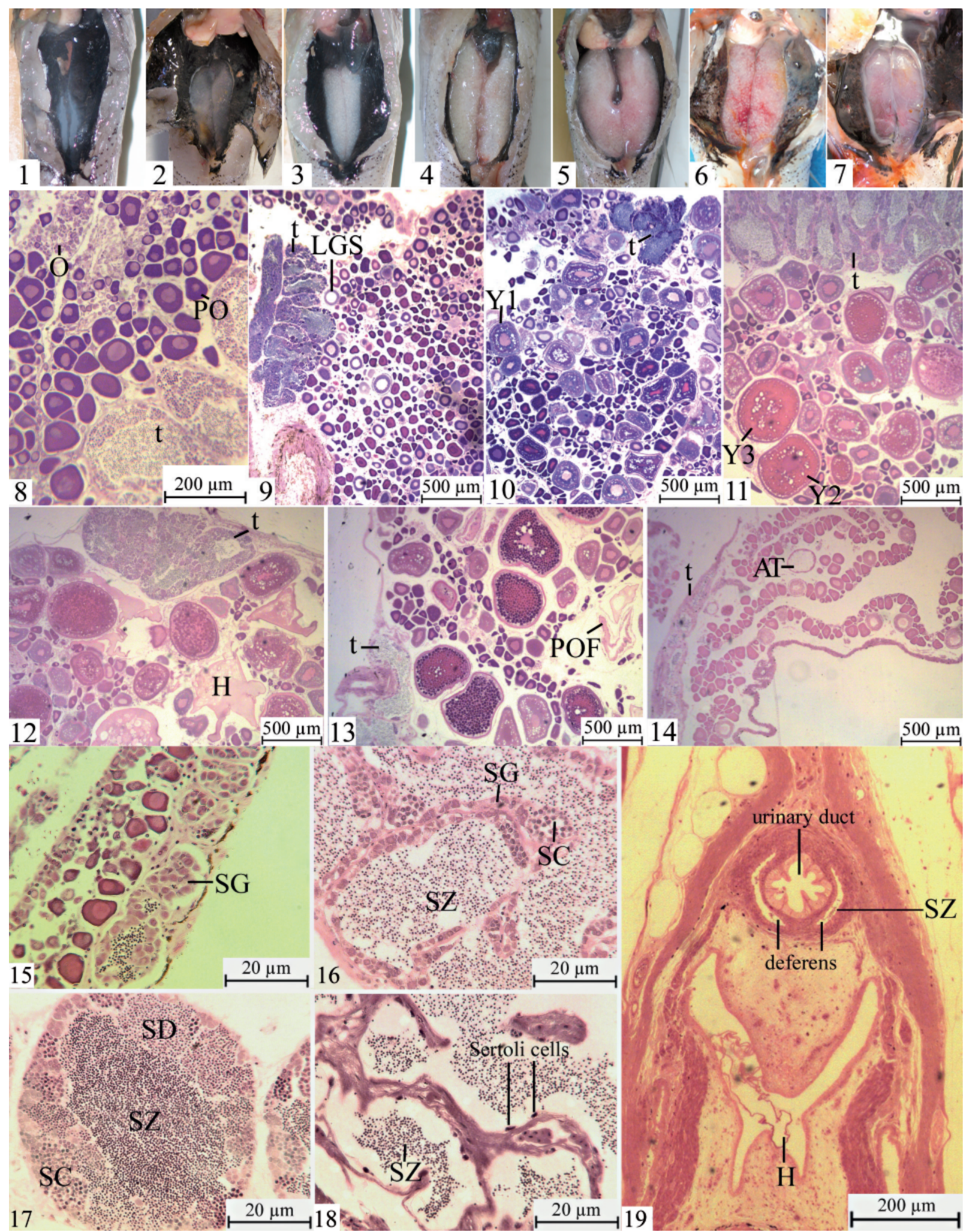

Figs. 1-19. Macroscopic and histological developmental stages of the gonads of Chlorophthalmus agassizi; Figs. 1, 8. Stage 1, virgin, September; Figs. 2, 9. Stage 2a, developing/virgin, Maj; Figs. 3, 10. Stage 2b, early developing, May; Figs. 4, 11. Stage 2c, late developing, June (Y2 = secondary vitellogenesis; Y3 = tertiary vitellogenesis); Figs. 5, 12. Stage 3, ripe/running, June; Figs. 6, 13. Stage 4a, post-spawning, September; Figs. 7, 14. stage $4 b$, spent, December reabsorbing; $(O=$ oogonia, $P O=$ primary oocytes, $t=$ testicular portion, LGS = lipid globul stage, $\mathrm{Y} 1$ = primary vitellogenesis, $\mathrm{H}=$ hydrated oocytes, $\mathrm{AT}=$ atretic oocytes, POF = post-ovulatory follicles); Figs. 15-19. Histological developmental stages of the testis of Chlorophthalmus agassizi and histological section of urogenital area; Fig. 15. Immature testis; Fig. 16. Developing testis; Fig. 17. Mature testis; Fig. 18. Spent testis; $(\mathrm{SG}=$ spermatogonia, $\mathrm{SC}=$ spermatocyte, $\mathrm{SZ}=$ spermatozoa, $\mathrm{SD}=$ spermatid). Fig. 19. Urogenital area (visible H oocytes and spermatozoa) 


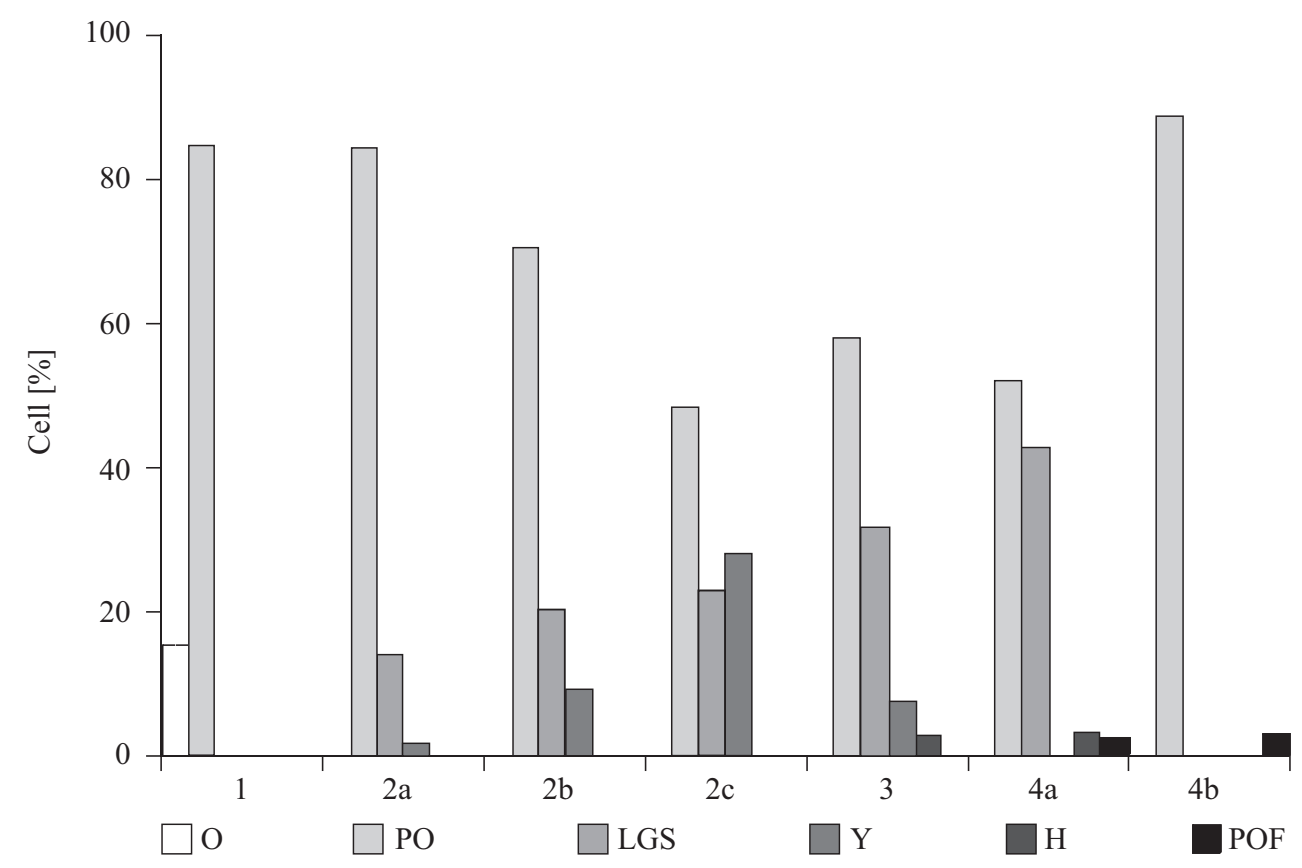

Figs. 20. Oocytes percentages at each developmental stage (stage $1=$ virgin; stage $2 a=$ developing/virgin; stage $2 b=$ early developing; stage $2 \mathrm{c}=$ late developing; stage 3 = ripe/running; stage $4 \mathrm{a}=$ post-spawning; stage $4 \mathrm{~b}=$ spent) ( $\mathrm{n}=$ number of fish, $\mathrm{O}=$ oogonia, $\mathrm{PO}=$ primary oocytes, LGS = lipid globule stage, $\mathrm{Y}=$ vitellogenesis, $\mathrm{H}=$ hydrated oocytes, $\mathrm{POF}=$ post-ovulatory follicles)

of the various stages of development (spermatogonia, spermatocytes, spermatids, spermatozoa) and cystic (Sertoli) cells. The germ cells within each cyst underwent synchronous development.

The shape, size and colour of the testis change less than those of the ovaries in relation to the developmental stage (Figs. 15-19); these were as follows:

1. Immature. The testis of young immature specimens $(n=4$; range $5.7-9.9 \mathrm{~cm}$ TL; mean $\pm \mathrm{SD}=7.8 \pm 1.8 \mathrm{~cm})$ is thin and white in colour. Spermatogonia (large spherical cells with central nucleus) are the main cell type in the cystis (Fig. 15). 2. Developing. Typically, the testis of developing specimens, $(n=53$; range $7.0-19.0 \mathrm{~cm}$ TL; mean $\pm \mathrm{SD}=11.7 \pm 2.8 \mathrm{~cm})$, appears similar in shape and colour and larger in size with respect to the previous stage. Spermatogonia are located close to the periphery of the cystis and spermatozoa occupy its greater part (Fig. 16).

3. Mature. The testis of mature specimens $(n=64$; range $9.3-17.9 \mathrm{~cm}$ TL; mean $\pm \mathrm{SD}=13.1 \pm 2.3 \mathrm{~cm})$ is thin due to the increase in the volume of the ovary component and is not visible to the naked eye (hidden by the ovary). Microscopically, spermatozoa are abundant in the lumina of the tubules and all the stages of spermatogenesis are present (Fig. 17).

4. Spent. The testis of spent specimens $(n=15$; range $13.1-19.5 \mathrm{~cm}$ TL; mean $\pm \mathrm{SD}=16.5 \pm 2.0 \mathrm{~cm})$, microscopically, appears disorganized with an increase of connective tissue. Phagocytosis by Sertoli cells occurs. Lobules are empty or contain residual diffuse spermatozoa; other stages of spermatogenesis are scarce (Fig. 18).

Size at maturity and reproductive cycle. Size at maturity was different when assessed for the male compo- nent of the gonad or for the female one (Fig. 21). The smallest specimen with a mature female component measured $10.9 \mathrm{~cm}$ TL and the mean size at first maturity $\left(\mathrm{TL}_{50}\right)$, achieved by the microscopic observation of the female component, was $12.0 \mathrm{~cm}$ TL. The smallest specimen with a mature male component measured $9.3 \mathrm{~cm}$ TL and the mean size at first maturity $\left(\mathrm{TL}_{50}\right)$, was $9.0 \mathrm{~cm}$ TL.

Gonadosomatic indices (GSI), ranging from $0.051 \%$ to $7.183 \%$, exhibited significant differences in their mean values in the different maturation stages (KW test, $P<0.05$ ). The GSI values did not fluctuate significantly between virgin (1) and developing/virgin (2a) stages (Q test, $P>0.05$ ), but increased progressively from developing/virgin (2a) to early developing (2b) and late developing (2c) stages ( $\mathrm{Q}$ test, $P<0.05$ ), remaining high in the ripe/running stage (3) (Q test, $P>0.05$ ) and decreased in the spent (4 b) stage (Q test, $P<0.05$ ).

The GSI varied significantly between months (KW test, $P<0.05)$; its monthly evolution showed low average values from January $(\mathrm{GSI}=0.366 \%)$ to April $(\mathrm{GSI}=0.454 \%)$ (Q test, $P>0.05$ ) (Fig. 22). In the following months, mean values inclined to increase (Q test, $P<0.05$ ), as the proportion of fish with mature gonads enlarged, peaking in the summer without significant variations in June (GSI $=2.881 \%$ ), July $(\mathrm{GSI}=3.164 \%$ ), and August (GSI $=3.277 \%$ ) (Q test, $P>0.05)$. The reproductive activity decreased significantly from September $(\mathrm{GSI}=2.245 \%)$ to November $(\mathrm{GSI}=0.454 \%)$ (Q test, $P<0.05$ ), but not between November and December $(\mathrm{GSI}=0.437)(\mathrm{Q}$ test, $P>0.05)$.

The hepatosomatic index (HSI) ranged from $0.089 \%$ to $3.075 \%$. The values did not show significant variations ( $Q$ test, 


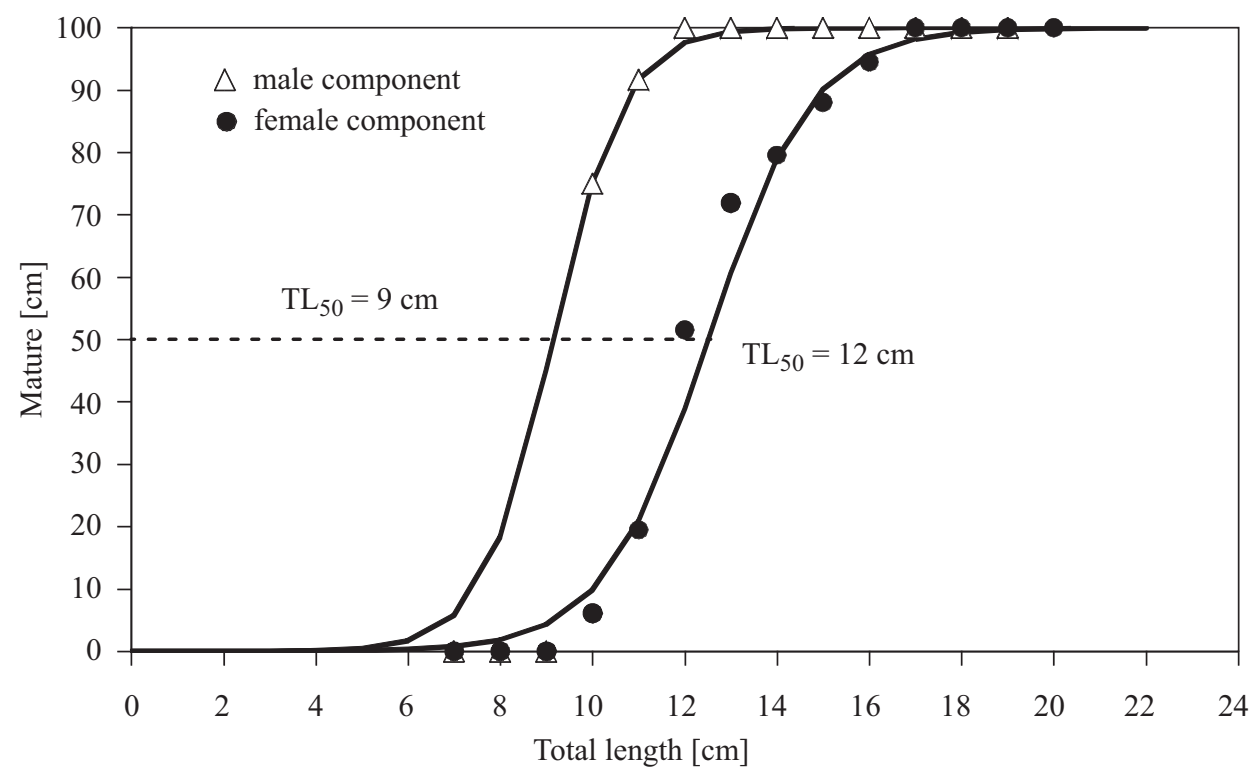

Figs. 21. Size at first maturity $\left(\mathrm{TL}_{50}\right)$ assessed taking into account the microscopic development of male and female portion of the gonad of Chlorophthalmus agassizi from Sardinian waters

$P>0.05$ ) between virgin (1), post spawning and spent stages (4a and $4 \mathrm{~b})$. The index decreased from virgin to developing/virgin (2a) and early developing (2b) stages (Q test, $P<0.05)$, and did not change significantly from the early developing stage (2b) to the ripe/running (3) stage ( $\mathrm{Q}$ test, $P>0.05$ ).

During the year, the HSI average values were high for a long period, from January (HSI $=1.495 \%$ ) to June $(\mathrm{HSI}=1.547 \%)(\mathrm{Q}$ test, $P>0.05)$, then decreased from July $(\mathrm{HSI}=1.175 \%)$ to August (HSI $=0.508 \%)(\mathrm{Q}$ test, $P<0.05)$ and remained low, in the following months, with no significant variations (Q test, $P>0.05)$ (Fig. 23).

The condition factor $(K)$ index ranged from $0.697 \%$ to $1.454 \%$ and was significantly lower for individuals of the virgin (1) stage than for individuals at any other stage (Q test, $P<0.05)$; its monthly evolution showed constant values from January $(K=1.073)$ to November $(K=1.071)$ (Q test, $P>0.05$ ), the December mean value being significantly higher $(K=1.168 \%)$ than any other month (Q test, $P<0.05)$ (Fig. 24).

The monthly distribution trend of the various ovary stages is in agreement with the results obtained from the indices related to reproduction. Specimens with virgin stage (1) (TL $<10 \mathrm{~cm})$ and developing/virgin stage (2a) ovaries were found from January to March (Figs. 25, 26). Vitellogenesis started in April when large specimens (TL $>17.8 \mathrm{~cm}$ ) have begun to accumulate yolky substances in the cytoplasm of oocytes. Specimens (TL $>11 \mathrm{~cm}$ ) with ripe/running ovaries were collected from May to September, the period considered as the spawning season with a peak in June. After June, the majority of the fishes examined (TL $>10.9 \mathrm{~cm})$ were post spawners and after August were spent (TL > 11.2 $\mathrm{cm})$. From November to December few specimens with spent ovaries were still present and from January all the specimens were in virgin and developing/virgin stages.

The testes were active from March to September for all the specimens larger than $9.3 \mathrm{~cm}$ TL. Inactive testes were found from November to February (Fig. 27).

\section{DISCUSSION}

Chlorophthalmus agassizi is a simultaneous hermaphrodite (Mead 1959), this characteristic is common among the Aulopiformes (Mead et al. 1964, Smith and Atz 1973, Merrett et al. 1973). The gonad appears like an ovotestis, where, throughout the year, the ovary is the most evident component. The simultaneous releasing of mature male and female gametes by an individual, during the reproductive period, is attested by the concomitant presence, in the ovotestis of vitellogenic oocytes and spermatozoa.

As a mature female may exhibit contemporaneously distinct populations of oocytes at progressive stages of development, this species shows an asynchronous ovarian pattern (Wallace and Selman 1981). The release of eggs in successive batches is also certified by the presence, in the same mature ovary, of oocytes undergoing vitellogenesis and post-ovulatory follicules; C. agassizi is, therefore, a partial deposition species.

In this paper $C$. agassizi gonads maturation staging has been achieved by macroscopic and histological features. Seven developmental stages for the ovary and four for the testis were identified. The maturing phase of the ovary was divided in two stages $(2 b, 2 c)$, due to the different ovary dimension and colour and to the presence of large eggs visible to the naked eye full of yolk globules. As the species is a fractional spawner, specimens that have already released one or more batches and were going to release the next series of hydrated eggs, were classified in the ripe/running stage. Moreover, the post-deposition phase was divided in two distinct stages (4a, post-spawning; 4b, spent). Post-deposition stages, substantially differ, from each other, by the ovary dimension and colour due to the presence, in the 4a stage, of oocytes not deposed and not yet totally resorbed appearing like yellow spots, and, in $4 \mathrm{~b}$ stage, the finding of mostly atretic advanced yolked oocytes and post-ovulatory follicules with numerous blood capillaries that confer a red colour 
to the ovary. The presence of degenerating ripe eggs and empty follicles in the spent ovaries is an indicator of recent spawning.

The reproductive season appears unique and well defined. The monthly changes of GSI values and maturation stages of ovaries show that the species is in a resting period from October to March. Vitellogenesis and spawning are lagging (April and May) behind ours in the Ionian Sea, as Anastasopoulou et al. (2006) identified the appearance, in March, of vitellogenic oocytes and detected, in April, spawning for the first time. The maximum reproductive activity took place in spring-summer (May-September), as observed also by Anastasopoulou et al. (2006) for the Ionian Sea. D'Onghia et al. (2006) found the greatest percentages of mature specimens during July and September, with a peak in September, but the authors didn't analyze samples in May, June and August.

The low values of the hepatosomatic index, during the reproductive season, may, suggest less active trophism in this period, as observed by stomach analysis (Cabiddu et al. 2005) probably due to the lower food availability. Moreover we observed a greater percentage (40\%) of empty stomachs (unpublished data) during the spawning period of this species (both for mature and immature specimens) with respect to the other months (17\%).

The testes, present more discreet morphological variations than the ovaries. In the early stages of development the testis, situated dorso-medially to the ovary, appears as a thin filament running along the entire length of the ovotestis. In mature stages it is thin and not visible macroscopically due to the increase in size of the ovary. Microscopically, the testis, appears like the unrestricted spermatogonial testis type where spermatogonia may occur along the entire length of the tubule, according to the distinction proposed by Grier (1981).

Specimens with a mature male portion of the gonad were found during a longer period (March-September), than specimens with a mature female portion, maturation beginning slightly earlier than that observed by Anastasopoulou et al. (2006) (April-November). The
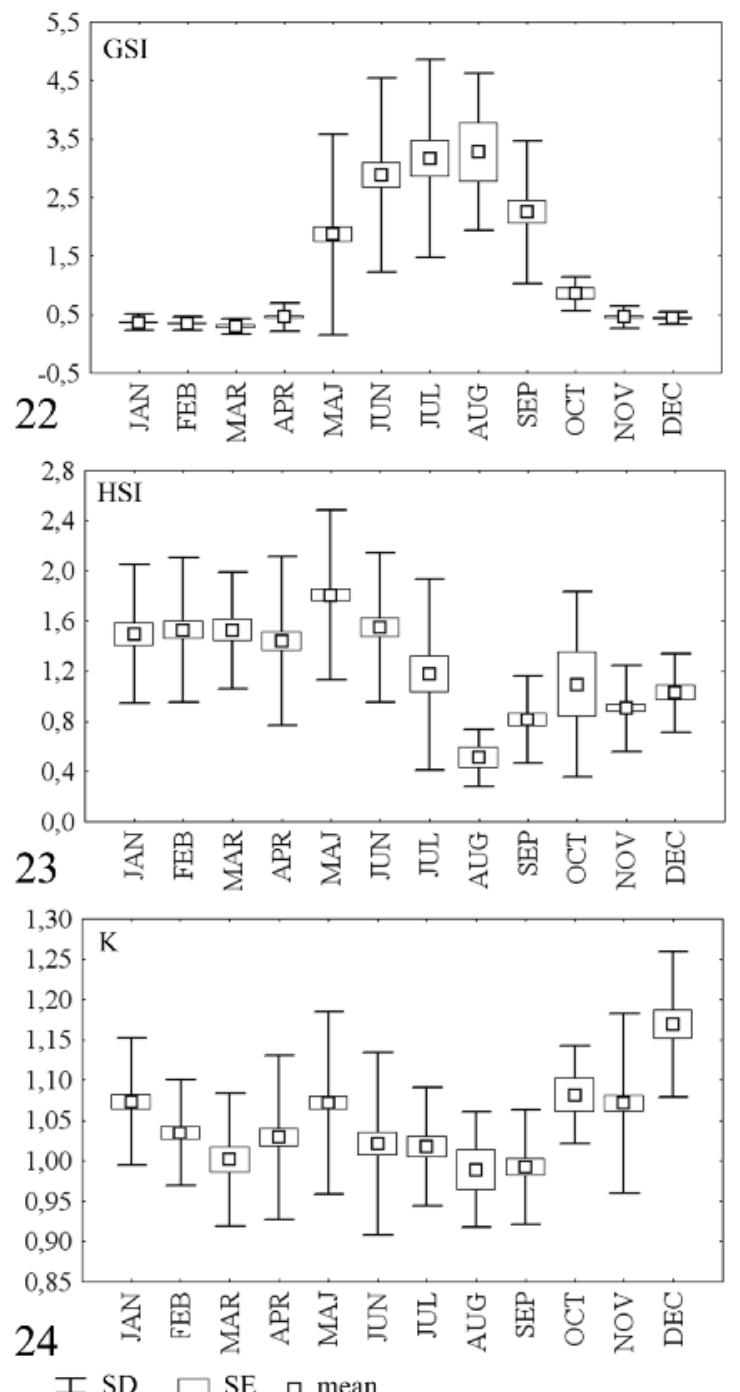

Figs. 22-24. Annual trend in: Fig. 22. Gonadosomatic index GSI, Fig. 23. Hepatosomatic index HSI and Fig. 24. Condition factor K of Chlorophthalmus agassizi from Sardinian waters 

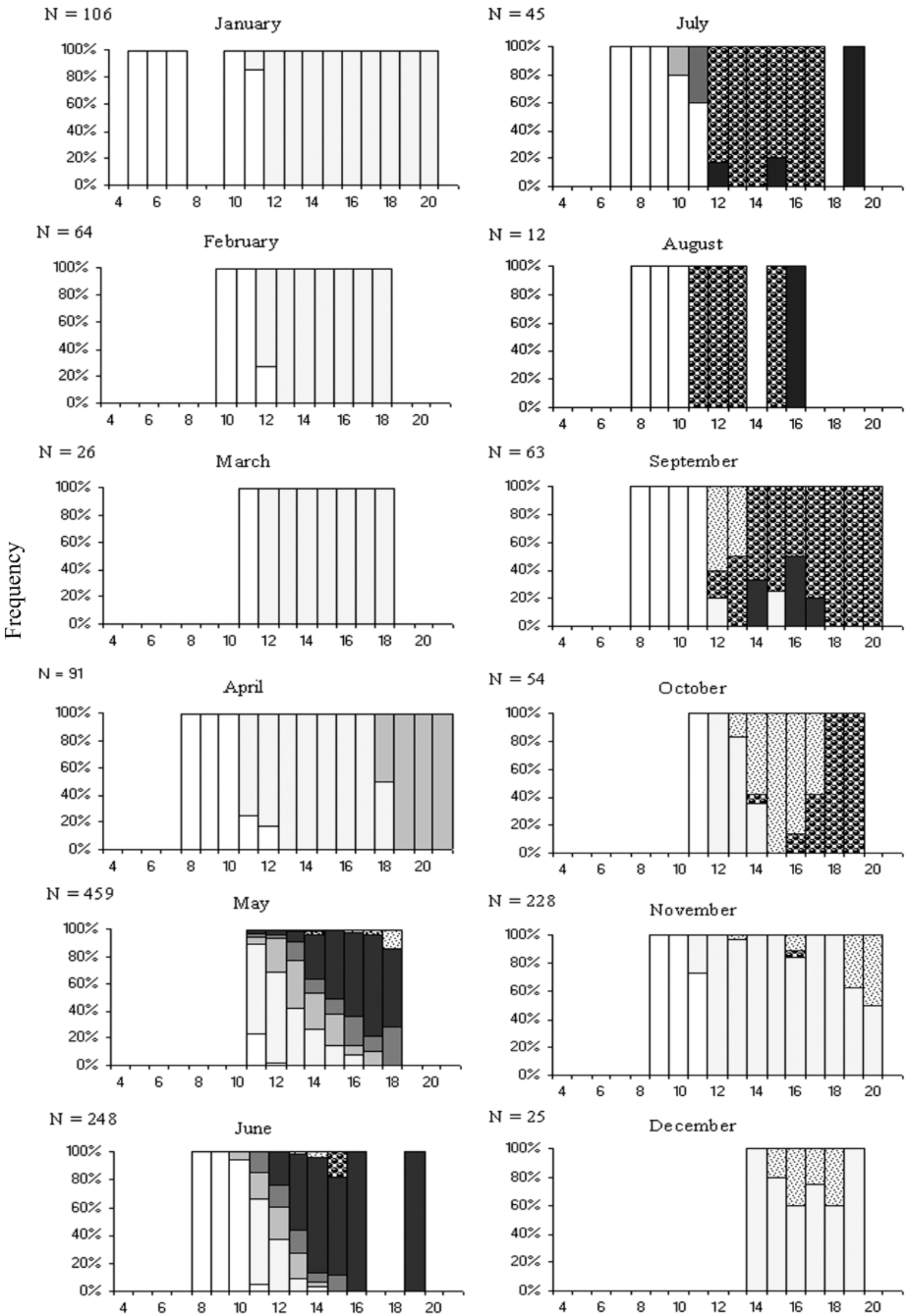

Stages $=\square 1 \square 2 \mathrm{a} \square 2 \mathrm{~b} \square 2 \mathrm{c} \square 3$ 圈 4a 图 4b Total length [cm]

Figs. 25. Monthly length distribution of ovarian stages of Chlorophthalmus agassizi from Sardinian waters. Stage 1 = virgin; stage $2 \mathrm{a}=$ developing/virgin; stage $2 \mathrm{~b}=$ early developing; stage $2 \mathrm{c}=$ late developing; stage 3 = ripe/running; stage $4 \mathrm{a}=$ post-spawning; stage $4 \mathrm{~b}=$ spent 

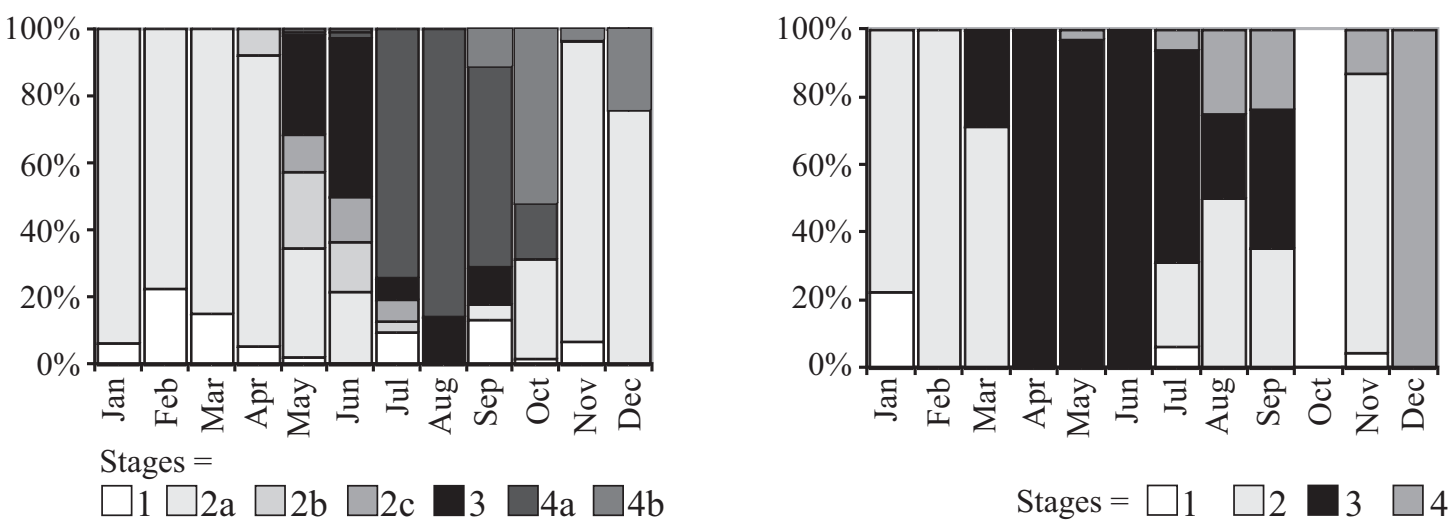

Figs. 26-27. Annual trend in: Fig. 26 percentage of occurrence of the different stages of development of the ovarian component of the ovotestis (stage $1=$ virgin; stage $2 \mathrm{a}=$ developing/virgin; stage $2 \mathrm{~b}=$ early developing; stage $2 \mathrm{c}=$ late developing; stage 3 = ripe/running; stage $4 \mathrm{a}=$ post-spawning; stage $4 \mathrm{~b}=$ spent), and Fig. 27 percentage of occurrence of the different stages of development of the testicular component of the ovotestis (stage 1 = immature; stage 2 = developing; stage 3 = mature; stage 4 = spent) of Chlorophthalmus agassizi from Sardinian waters

longer spawning period of the male portion is observed also in other simultaneous hermaphroditic species as Bathypterois mediterraneus from the Sardinian waters (Porcu et al. 2010).

The range of size of the specimens recorded in this study (4.7-20.4 cm TL) was similar to that analyzed for the Ionian populations by D'Onghia et al. (2006) (4.5-20.1 cm TL), and slightly larger than those analyzed by Anastasopoulou et al. (2006) (3.8-18.9 cm TL). The size at first maturity calculated by D'Onghia et al. (2006), considering only the female portion of the gonads, was slightly lower $(11.5 \mathrm{~cm} \mathrm{TL})$ than those calculated in this work (12.0 cm TL). These differences may be due to the different period of sampling. D'Onghia et al. (2006), in fact, analyzed the pooled data for only two months (July and September), while in this study the mean size at maturity was determined on specimens collected during the whole reproductive season. Moreover, D'Onghia et al. (2006) found that during July and September mature specimens start at the size of $8.4 \mathrm{~cm} \mathrm{LT}$, while the smallest specimen with the mature female component that we found measured $10.9 \mathrm{~cm}$ TL. Moreover, the length at first maturity, calculated by taking into account the development of the male portion $(9.0 \mathrm{~cm} \mathrm{TL})$, was lower than that evaluated on the basis of female portion development $(12.0 \mathrm{~cm}$ TL); such differences are due to the earlier development of the male component of the ovotestis. Testis, indeed, reaches the mature (3) stage in specimens still having virgin (1) and developing/virgin (2a) ovaries, and extends the mature condition until the ovary is in post-spawning and spent stages. The male spent stage is mainly present in specimens with the ovary in post deposition stages $(78 \%)$.

During the reproductive season small specimens (7.1-10.9 cm TL) show a mature or developing testis and an immature ovary. Suggesting that $C$. agassizi reproduces through a release, in sea water, of sperm and mature eggs by different individuals. In specimens longer than about $10.9 \mathrm{~cm}$ (TL) self-fertilization could be possible, due to the contemporary presence and release of spermatozoa and mature eggs (Fig. 19) and to the morphology of the terminal portion of the reproductive apparatus (the male and female genital tracts meet as one at the same opening), as also observed by Follesa et al. (2004a).

Hermaphroditic Aulopiformes representing genera Chlorophthalmus and Bathypterois, are deep water species in which hermaphroditism might be favoured for reasons of low population density (Mank et. al. 2006). Chlorophthalmus agassizi, however, has a high population density and is able to make large vertical and horizontal movements that could facilitate meeting with sexual partners. This species, moreover, as observed by De Domenico et al. (1990), shows a luminous organ of symbiotic bacteria (Photobacterium) in the perianal area, consisting of an invagination with specific finger-like structures emitting small spot like bioluminescence. This signal, as observed by Somiya (1977) for C. albatrossis and C. nigromarginatus could be intercepted by the specialized eyes of the Chlorophthalmidae and could be used as an intraspecific signal for sexual attraction.

In conclusion, this study describes the reproductive characteristics of both components of the gonads of C. agassizi. The information on the spawning period and details on the size at sexual maturity should assist in establishing guidelines for the management of this species. C. agassizi shows a defined, but protracted spawning season, from May to September with a release of eggs in successive batches. A longer spawning period also indicates that favourable environmental conditions for hatching and larval development are available for a longer period (Gonçalves and Erzini 2000, Pajuelo et al. 2006). However this species, shows a longevity of more than 10 years (D’Onghia et al. 2006) and a relatively late maturation, which are considered important with respect to management (Booth and Buxton 1997). These characteristics make the species more vulnerable to fishing exploitation and can result in possible overfishing. 


\section{REFERENCES}

Anastasopoulou A., Kapiris K. 2007. Feeding ecology of the shortnose greeneye Chlorophthalmus agassizi Bonaparte, 1840 (Pisces: Chlorophthalmidae) in the eastern Ionian Sea (eastern Mediterranean). Journal of Applied Ichthyology 24 (2): 170-179. DOI: 10.1111/j.1439-0426.2007.01028.x.

Anastasopoulou A., Yiannopoulos C., Megalophonou P., Papaconstantinou C. 2006. Distribution and population structure of the Chlorophthalmus agassizi (Bonaparte, 1840) on an unexploited fishing ground in the Greek Ionian Sea. Journal of Applied Ichthyology 22 (6): 521-529. DOI: $10.1111 /$ j.1439-0426.2006.00782.x.

Bini G. 1970. Atlante dei pesci delle coste italiane. Vol. 2. Osteitti. [Atlas of fishes of the Italian coast. Vol. 2. Osteichthyes.] Mondo Sommerso Editrice, Roma. [In Italian.]

Booth A.J., Buxton C.D. 1997. Management of the panga Pterogymnus laniarius (Pisces: Sparidae), on the Agulhas Bank, South Africa using per-recruit models. Fishery Research 32 (1): 1-11. DOI: 10.1016/S0165-7836(97)00045-3.

Cabiddu S., Follesa M.C., Cuccu D., Porcu C., Cau A. 2005. Dieta di Chlorophthalmus agassizi Bonaparte, 1840 nel Mediterraneo centro-occidentale. [Diet of Chlorophthalmus agassizi (Bonaparte, 1840) in the central-western Mediterranean.] Biologia Marina Mediterranea 12 (1): 475-479. [In Italian.]

Cau A., Mura M. 1978. Notizie sulla pesca bentobatiale nei mari della Sardegna Meridionale. [Information on deep sea fishing in Southern Sardinia.] Rendiconti del Seminario della Facoltà di Scienze dell'Università di Cagliari Suppl. vol 48: 137-147. [In Italian.]

D’Onghia G., Sion L., Maiorano P., Mytilineou Ch., Dalessandro S., Carlucci R. Desantis S. 2006. Population biology and life strategies of Chlorophthalmus agassizi Bonaparte, 1840 (Pisces: Osteichthyes) in the Mediterranean Sea. Marine Biology 149 (3): 435-446. DOI: $10.1007 / \mathrm{s} 00227-005-0231-\mathrm{y}$.

De Domenico M., De Domenico E., Genovese L., Cau A., Davini M.A., Deiana A.M., Salvadori S., Laudani U. 1990. L'organo luminoso a batteri simbionti di Chlorophthalmus agassizi Bp.: primi risultati. [The light organs of symbiotic bacteria in Chlorophthalmus agassizi Bp.: First results.] P. 160. In: Atti del 53 Congresso dell'Unione Zoologica Italiana, 1-5 ottobre 1990, Palermo. [In Italian.]

Dunn O.J. 1964. Multiple contrasts using ranks sums. Technometrics 6 (3): 241-252.

Fischer W., Bauchot M.L., Schneider M. 1987. Mediterranée et Mer Noire. Zone de peche 37. Fiches FAO d'identification des espèces pour le besoins de la peche. (Révision 1). 2. Vertébrés. FAO, Roma.

Follesa M.C., Cabiddu S., Davini M.A., Porcu C., Cau A. 2004a. Reproductive biology of Chlorophthalmus agassizi in the central-western Mediterranean. Rapport de la Commission Internationale pour la Mer Méditerranée 37: 356.

Follesa M.C., Cabiddu S., Ortu A., Sabatini A., Cau A. 2004b. Demersal assemblages on the slope in the Sardinian Channel (Central Western Mediterranean Sea). Biologia Marina Mediterranea 11 (3): 171.

Follesa M.C., Porcu C., Cabiddu S., Mulas A., Deiana A.M., Cau A. 2010. Deep-water fish assemblages in the central-west- ern Mediterranean (south Sardinian deep-waters). Journal of Applied Ichthyology DOI: 10.1111/j.1439-0426.2010.01567.x.

Forberg K.G. 1982. A histological study of development of oocytes in capelin, Mallotus villosus villosus (Müller). Journal of Fish Biology 20 (2): 143-154. DOI: $10.1111 /$ j.1095-8649.1982.tb03915.x.

Gonçalves J.M.S., Erzini K. 2000. The reproductive biology of the two-banded sea bream (Diplodus vulgaris) from the southwest coast coast of Portugal. Journal of Applied Ichthyology 16 (3): 110-116. DOI: 10.1046/j.1439-0426.2000.00232.x.

Grier H.J. 1981. Cellular organization of the testis and spermatogenesis in fishes. American Zoologist 21 (2): 345-357.

Hollander M., Wolfe D.A. 1973. Nonparametric statistical methods. Wiley, New York.

Kabasakal H. 1999. A note on the diet of five deep-sea fishes from the North-eastern Aegean Sea. Bilješke-Notes 1973 (82): $1-6$.

Mank J.E., Promislow D.E.L., Avise J.C. 2006. Evolution of alternative sex-determining mechanism in teleost fishes. Biological Journal of the Linnean Society 87 (1): 83-93. DOI: $10.1111 / \mathrm{j} .1095-8312.2006 .00558 . x$.

Mazzi V. 1977. Manuale di tecniche istologiche e istochimiche. [Handbook of histological and histochemical techniques.] Edizioni Piccin, Padova. [In Italian.]

Mead G.W. 1959. Hermaphroditism in archibenthic and pelagic fishes of the order Iniomi. Deep Sea Research 6: 234-235. DOI: 10.1016/0146-6313(59)90076-0.

Mead G.W., Bertelsen E., Cohen D.M. 1964. Reproduction among deep-sea fishes. Deep-Sea Research and Oceanographic Abstracts 11 (4): 569-596.

DOI: 10.1016/0011-7471(64)90003-8.

Merrett N.R., Badcock J., Herring P.J. 1973. The status of Benthalbella infans (Pisces: Myctophoidei), its development, bioluminescence, general biology and distribution in the eastern North Atlantic. Journal of Zoology 170 (1): 1-48. DOI: 10.1111/j.1469-7998.1973.tb05042.x.

Pajuelo J.G., Lorenzo J.M., Bilbao A., Ayza O., Ramos A.G. 2006. Reproductive characteristics of the benthic coastal fish Diplodus vulgaris (Teleostei: Sparidae) in the Canarian archipelago, northwest Africa. Journal of Applied Ichthyology 22 (5): 414-418. DOI: 10.1111/j.1439-0426.2006.00766.x.

Porcu C., Follesa M.C., Grazioli E., Deiana A.M., Cau A. 2010. Reproductive biology of a bathyal hermaphrodite fish, Bathypterois mediterraneus (Osteichthyes: Ipnopidae) from the south-eastern Sardinian Sea (central-western Mediterranean). Journal of the Marine Biological Association of the United Kingdom 90 (4): 719-728. DOI: $10.1017 / \mathrm{S} 0025315409991330$.

Relini G., Bertrand J., Zamponi A. 1999. Sintesi delle conoscenze sulle risorse da pesca dei fondi del Mediterraneo centrale (Italia e Corsica). [Synthesis of the knowledge on bottom fishery resources in central Mediterranean (Italy and Corsica).] Biologia Marina Mediterranea 6 (Suppl. 1): 165-168. [In Italian.]

Robins C.R., Ray G.C. 1986. A field guide to Atlantic coast fishes of North America. Houghton Mifflin, Boston, MA, USA.

Scott W.B., Scott M.G. 1988. Atlantic fishes of Canada. Canadian Bulletin of Fisheries and Aquatic Sciences No. 219. 
Smith C.L., Atz E.H. 1973. Hermaphroditism in the mesopelagic fishes Osmosudis lowei and Alepisaurus ferox. Copeia 1973 (1): 41-44.

Somiya H. 1977. Bacterial bioluminescence in chlorophthalmid deep-sea fish: a possible interrelationship between the light organ and the eyes. Experientia 33 (7): 906-909.

DOI: $10.1007 / \mathrm{BF} 01951274$

Wallace R.A., Selman K. 1981. Cellular and dynamic aspects of oocyte growth in teleosts. American Zoologist 21(2): 325-343. DOI: 10.1093/icb/21.2.325.
Zar J.H. 1996. Biostatistical analysis. Third edn. Prentice Hall, New Jersey.

Received: 11 January 2010

Accepted: 27 October 2010

Published electronically: 15 December 2010 